\section{A NEW SYNTHESIS OF INDIGO.}

A $\mathrm{N}$ important new synthesis of indigo is described by $\mathrm{Dr}$. T. Sandmeyer in the April number of the Zeitschrift für Farben-und Textil-Chemie. The starting point for the synthesis is thiocarbanilid, $\mathrm{CS}\left(\mathrm{NH} . \mathrm{C}_{6} \mathrm{H}_{5}\right)_{2}$, which is converted in one operation by the simultaneous action of white lead and potassium cyanide into the hydrocyanide, $\mathrm{C}_{6} \mathrm{H}_{5} \cdot \mathrm{N}: \mathrm{C}(\mathrm{CN}) \cdot \mathrm{NH} \cdot \mathrm{C}_{6} \mathrm{H}_{5}$, of carbodiphenylimide. This compound is changed by the action of yellow ammonium sulphide into the thioamide,

$$
\mathrm{C}_{6} \mathrm{H}_{5} \cdot \mathrm{N}: \mathrm{C}\left(\mathrm{CS} . \mathrm{NH}_{2}\right) \cdot \mathrm{NH} \cdot \mathrm{C}_{6} \mathrm{H}_{5} \text {, }
$$

which, when stirred into warm sulphuric acid, undergoes condensation, and yields an $\alpha$-isatinanilide,

$$
\mathrm{C}_{6} \mathrm{H}_{5}\left\langle{ }_{\mathrm{CO}}^{\mathrm{NH}}>\mathrm{C}: \mathrm{NC}_{6} \mathrm{H}_{5}\right. \text {. }
$$

The anilide is converted directly into indigo when dissolved in alcohol and reduced with ammonium sulphide, but the indigo separates in glistening crystals which cannot easily be reduced by the ordinary methods, and so is unsuitable for commercial use. A better method, and one which renders it unnecessarys to separate the isatinanilide from the sulphuric acid used in its preparation, consists in allowing the acid solution to flow into ice-water simultaneously with a solution of sodium sulphide, when the anilide is converted into thioisatin,

$$
\mathrm{C}_{6} \mathrm{H}_{4}\left\langle\mathrm{CO}_{\mathrm{CS},}^{\mathrm{NH}}\right\rangle_{\mathrm{CS}}
$$

which is thrown down as a bulky precipitate. In order to prepare the indigo it is now only necessary to make the precipitate into a thin paste and mix it with a little alkali, when the thioisatin rapidly decomposes into indigo and sulphur. The sulphur is removed by extracting with carbon disulphide, and the indigo is left in the form of light, darkblue blocks, which readily crumble when rubbed between the fingers, and can be made into a uniform paste which is easily reduced to indigo-white. The patents are held and are being worked by J. R. Geigny, of Basle, and the process may prove to be a formidable rival not only to natural indigo, but also to the synthetical process employed by the Badische Anilin- und Soda-Fabrik.

\section{UNIVERSITY AND EDUCATIONAL} INTELLIGENCE.

OXFord, - The 249th meeting of the Junior Scientific Club was held on May 20. Mr. H. S. Souttar gave an exhibit of an automatic method of drawing capillary tubes intended for use in the capillary electrometer. Mr. S. A. Ionides read a paper on "Mining in Cornwall," in which he gave an account of the methods employed for raising and washing the tin ores.

CAMBRIDGE.-Mr. Andrew Graham, who has for nearly forty years held the office of chief assistant at the observatory, and is known to astronomers as the discoverer of ILetis, is retiring at the age of eighty-eight. It is proposed to assign him a pension of $200 l$. a year.

The use of the Senate House has been granted to the local conmittee of the British Association for the meeting to be held in Cambridge next year.

LORD KELVIN and Lord Lister are to receive the honorary degrees of doctor of science from the University of Wales next November.

Mr. W. M. Childs, vice-principal of University College, Reading, has been elected principal of the College in succession to Mr. H. J. Mackinder, who resigns office in September next.

IT is stated by the Electrician that a donation of nearly $40,000 l$. has been promised by Lord Iveagh to Trinity College, Dublin, with the object of building and equipping scientific laboratories.

THE Liverpool University Bill was, on Tuesday, reported for third reading by Lord Morley, Chairman of Committees of the House of Lords. The object of the Bill is to separate University College, Liverpool, from the Victoria University, and to merge it into the University of Liverpool.

TuE annual report of the Royal Agricultural Society, which was adopted at the general meeting held on May 22, states that with the view of bringing before the public the general characteristics of the teaching now provided at agricultural colleges, and of directing attention to the Society's own share in this work as a national examining body, the council has decided to organise an agricultural education exhibition as a new feature of its annual show.

IN his recent paper read at a meeting of the Society of Arts Mr. G. T. Morrison gave a clear and useful account of the modern methods of construction of maps and charts. His descriptions of orthographic, stereographic, Mercator's, gnomonic and elliptical projections should prove of great assistance to teachers who wish to explain the methods employed to make maps, which either give good general ideas of the appearance of the whole or of parts of the earth, or retain some one property of the sphere at the expense of disregarding the others. Mr. Morrison thinks that for the purpose of teaching geography a projection based, not on any distinct mathematical rule, but on a system of compromise, is on the whole the best-one, for example, on which the meridians and parallels are spaced at equal distances throughout.

ARrangements have been made for an allied colonial universities dinner and conference to be held early in July. The conference will be held on July 9 at the rooms of the Royal Society, Burlington House (by permission of the president), to discuss the question of the coordination of university education throughout the King's dominions, and the development of post-graduate courses in applied science. It is expected that an Imperial council will be formed to deal permanently with these interests. The dinner will be heid on Friday, July io, at the Hotel Cecil. The Lord Chancellor and other statesmen, many high public officials, representatives of colleges and universities in the United Kingdom and the colonies, and several distinguished men of science are expected to be present. Graduates and undergraduates of colonial universities wishing to attend the dinner, or to take part in the conference, are requested to write as soon as possible to $\mathrm{Mr}$. C. Kinloch Cooke, hon. sec., 3 Mount Street, London, W.

THE annual catalogue, 1902-3, of the Massachusetts Institute of Technology at Boston gives very full particulars of the numerous courses of instruction in connection with the institute, a clear plan of the extensive buildings, a register of graduates, and other interesting details. The tuition fee for regular students is $50 l$. per annum, for half a year or any shorter period the fee is $30 l$. Special students pay, in general, the full fee; but when a few branches only are pursued and the time required for instruction is limited, applications for a reduction in the fess are considered. Regular students whose financial necessities are such as to prevent their continuance at the institute are encouraged to apply for aid to the scholarship committee of the faculty. Students may conveniently live in any of the nearer cities or towns, since the hours of the institute are from 9 to 5. The cost of board and rooms in Boston and the neighbouring towns need not exceed from thirty shillings to tivo pounds a week. The cost of books and material varies from five to seven pounds a year.

THE second clause of the London Education Bill, referring to the constitution of the education committee was withdrawn by the Government on Monday. In its original form the Bill provided for the appointment of thirty-one representatives of the borough councils upon the committee. This number was reduced to twelve in Committee of the House of Commons last week, but the compromise pleased nobody, so the whole clause, with its restrictions upon the local authority with regard to the constitution of the Education Committee, has been omitted from the Bill. By this action the London County Council, so far as the constitution of its education committee is concerned, is placed in precisely the same position as other local authorities brought into being by the Act of last year. The Council will frame a scheme for itself, just as other county councils have done, or are doing, and under the same conditions. 